\title{
EPINEPHRINE-INDUCED DYSRHYTHMIAS: COMPARISON DURING ANAESTHESIA WITH NARCOTICS AND WITH HALOGENATED INHALATION AGENTS IN DOGS
}

\author{
Belgio A. Puerto, K.C. Wong, Ana X. Puerto, C.K. Tseng and Richard A. Blatnick
}

IT IS GENERALLY BELIEVED that the use of a nurcotic-nitrous oxide-muscle relaxant technique, popularly known as "balanced anaesthesia", is better tolerated by patients with labile cardiovascular function than is general anaesthesia with halogenated inhalation agents, nitrous oxide and muscle relaxants. Epinephrineinduced cardiac dysrhythmias have been widely studied with halogenated inhalation agents and oxygen as the anaesthetic regimen, ${ }^{1.5}$ without the addition of nitrous oxide, which is a frequent adjunct in clinical anaesthesia. The purpose of this study was to evaluate the arrhythmogenicity of epinephrine in dogs anaesthetized with morphine, fentanyl or meperidine with nitrous oxide and petncuronium and to compare this with a second group of animals anaesthetized with halothane, enflurane or methoxyflurane with nitrous oxide and pancuronium.

\section{METHOD}

In sixteen mongrel dogs weighing $15-20 \mathrm{~kg}$ anaesthesia was induced with intravenous thiopentone $15-20 \mathrm{mg} \cdot \mathrm{kg}^{-1}$ to facilitate tracheal intubation and the lungs were ventilated mechanically to maintain a $\mathrm{Pa}_{\mathrm{CO}_{2}}$ of $4.6-5.33 \mathrm{kPa}$ (3540 torr). Eight animals in Group I received 1.2 MAC halothane ( 1.0 per cent), enflurane ( 2.6 per cent) or methoxyflurane $(0.28 \mathrm{per}$ cent $)$ in $50 \mathrm{per}$ cent nitrous oxide with oxygen at a flow rate of five litres per minute, according to the MAC concentrations of these anaesthetics reported by Eger.6 The end tidal $\mathrm{PCO}_{2}$, halothane and enflurane were measured continuously by Beckman Infra-red Analyzers. Eight animals in Group

Belgio A. Puerto, M.D., K.C. Wong, M.D., Ph.D.. Ana X. Puerto. M.D.. C.K. Tseng. M.D., and Richard A. Blatnick, M.S., Department of Anesthesiology, University of Utah College of Medicine, 50 North Medicat Drive, Salt Lake City, Utah 84132, U.S.A. Reprint requests to K.C. Wong, M.D.

Supported by a grant from the Utah Heart Association.

two received two intrave nous doses of each narcot. ic administered 60 minutes apart: morphine 1 and $2 \mathrm{mg} \cdot \mathrm{kg}^{-1}$. fentanyl 0.01 and $0.02 \mathrm{mg} \cdot \mathrm{kg}^{-1}$ and meperidine 10 and $20 \mathrm{mg} \cdot \mathrm{kg}^{-1}$, also with an inspired gas mixture of nitrous oxide 50 per cent with oxygen. Both groups received intravenous pancuronium $0.2 \mathrm{mg} \cdot \mathrm{kg}^{-1}$. Each animal in Group I or Group 2 was studied three times, but only once a week and one anaesthetic regimen per study. The order of administration of the anaesthetic regimen was randomized for both groups.

Lead II of the electrocardiogram, oesophageal temperature and arterial pressure were monitored continuously. Oesophageal temperature was maintained at $37 \pm 1^{\circ} \mathrm{C}$ throughout the study. Heating pads were used when necessary. The arterial pressure was taken from a two-inch catheter inserted percutaneously into the femoral artery from which blood gases and serum sodium $(\mathrm{Na})$ and potassium $(\mathrm{K})$ were determined before epinephrine infusion when the preparation was stabilized, during the peak pressure response from epinephrine infusion and every 30 minutes for the rest of the experiment. Five per cent dextrose in lactated Ringer's solution was infused to maintain a mean arterial pressure of $10.66 \pm 1.33$ $\mathrm{kPa}(80 \pm 10$ torr) during the anaesthetic course. This varied from 7 to $22 \mathrm{ml} / \mathrm{kg}$ with a mean of 12 $\mathrm{ml} / \mathrm{kg}$. When the preparation became stable in $30-45$ minutes. epinephrine $5 \mu \mathrm{g} / \mathrm{ml}$ was infused at a rate of $1 \mu \mathrm{g} \cdot \mathrm{kg}^{-1} \cdot \mathrm{min}^{-1}$ up to ten minutes, with a Harvard syringe pump. In eight of $24 \mathrm{ex}$ periments in Group 1 the epinephrine infusion was stopped after about five minutes because of the development of ventricular tachycardia (VT) or ventricular fibrillation (VF). All but one of the 48 epinephrine infusions in Group 2 went to completion with a total of $10 \mu \mathrm{g} \cdot \mathrm{kg}^{-1} \cdot \min ^{-10}$ (see REsults). The occurrence of three or more consecutive dysrhythmic beats was used as the endpoint of the epinephrine arrhythmogenic dose.

Statistical comparisons were made using the Student's t-test for paired and unpaired data. $P$ values less than 0.05 were considered significant. 


\section{Results}

The peak mean arterial blood pressure increases from epinephrinc infusion in all treatment groups varied from $6.6-10.66 \mathrm{kPa}$ (50-80 torr) and were not significantly different among groups. However, the mean arterial blood pressures of animals anaesthetized with meperidinenitrous oxide-pancuronium, before epinephrine infusion, were generally $1.33-4.0 \mathrm{kPa}(10-30$ torr') lower than the animals anaesthetized by the other regimen; therefore, larger quantities (15-20 $\mathrm{ml} / \mathrm{kg}$ ) of 5 per cent dextrose in lactated Ringer's solution were infused to maintain the mean arterial pressure of $10.66 \mathrm{kPa}$ ( 80 torr)

Arterial blood gases showed minimal changes in both groups, and there were no significant differences among groups during the course of the experiment. The pooled values $(\mathrm{N}=216$, mean \pm SD) were $\mathrm{Pa}_{\mathrm{O}_{2}} 24 \pm 2.13 \mathrm{kPa}(180 \pm 16$ torr $)$. $\mathrm{Pa}_{\mathrm{CO}}$ $4.8 \pm 0.4 \mathrm{kPal}\left(36 \pm 3\right.$ torr) and $\mathrm{cH}^{+} 43.65 \pm 0.14$ $\mathrm{nmol} / \mathrm{l}(\mathrm{pH} 7.36 \pm 0.07)$. Control serum sodium was $142 \pm 5 \mathrm{mmol} / \mathrm{l}$ and serum potassium was 4.1 $\pm 0.3 \mathrm{mmol} / \mathrm{l}$. Serum sodium did not change significantly during the course of the experiments, but serum potassium increased to a peak concentration of $6.5 \pm 0.4 \mathrm{mmol} / 1$ at $4.3 \pm 1.2$ minutes following the infusion of epinephrine (4.3 $\left.\pm 0.9 \mu \mathrm{g} \cdot \mathrm{kg}^{-1}\right)$. The peak serum potassium changes were not significantly different among groups during the epinephrine infusion.

The dose of epinephrine that induced dysthythmias during narcotic-nitrous oxide anaesthesia is summarized in Table 1 . The arrhythmogenic dose tended to be higher for morphine in comparison with fentanyl or meperidine. but not statistically significant. We were not able to demonstrate a dose-response relationship at the doses studied. The ventricular dysrhythmia dose was generally higher than the corresponding supraventricular dose for each anaesthetic regimen. Out of 48 epinephrine challenges in the eight dogs anaesthetized with narcotics and nitrous oxide ventricular tachycardia was observed only once during fentanyl-nitrous oxide anaesthesia (Table I).

The dose of epinephrine that induced dysrhythmias during anaesthesia with the halogenated agents and nitrous oxide is summarized in Table II. There was no significant difference between the arrhythmogenic doses among the halogenated agents studied. The ventricular dysrhythmic doses were generally higher than their corresponding supraventricular dysrhythmic doses during the same anaesthetic regimen. The incidence of ventricular dysthythmias was less during methoxyfiurane-nitrous oxide antesthesia $(4 / 8)$ than with halothane-nitrous oxide $(8 / 8)$ and enflurane-nitrous oxide $(8 / 8)$ anaesthesia (Table II). The ventricular dysrhythmias observed during halothane-nitrous oxide or enflurane-nitrous oxide anaesthesia were multifocal and associated with bigeminy to quadrageminy, whereas those obselved during methoxyflurane-nitrous oxide were usually unifocal dispersed with bigeminy only. The arrhythmogenic doses in the halogenated anaesthesia groups were significantly higher than in the narcotic anclesthesia groups; however. the incidence of ventricular dysrhythmias was greater in the halogenated aniesthesia groups $(20 / 24$ vs $20 / 48)$. Ventricular tachycardia and/or ventricular fibrillation occurred in five out of eight epinephrine challenges in the halothane group, three out of eight in the enflurane group and in none of the eight in the methoxyflurane-nitrous oxide group (Table II).

\section{Discussion}

Intravenous epinephrine was first used as a method of inducing cardiac dysrhythmias in dogs in the classic publication of Meck, ef al. in 1937. More recently, others have used the appearance of ventricular extrasystoles as the end point following incremental doses of epinephrine. ${ }^{2-4}$ The use of epinephrine for evaluating the arrhythmogenic potential of anaesthetics is clinically meaningful because intraoperative cardiac dysthythmias are frequently associated with imbalance of the autonomic nervous system, usually a preponderance of sympathetic activity, and epinephrine is still commonly used to reduce surgical bleeding,

Factors ${ }^{5}$ which are known to potentiate catecholamine-induced cardiac dysthythmias are hypoxia, hypercarbia, hypertension and electrolyte imbalance, especially hyper- or hypokalaemia. ${ }^{7}$ The arterial blood gases obtained during this study would tend to eliminate hypoxia and hypercarbia as contributing factors. Hypertension during epinephrine infusion was not controlled in our study, but blood pressure elevations were not significantly different among the groups. The combination of meperidine and nitrous oxide tended to be more hypotensive than the other anaesthetic regimen in the dog, but the hypotension was easily overcome by intravascular infusion. Once stabilized, the blood pressure of al animals was well maintained throughout the experimental period. Epinephrine is known to re- 
TABLE I

Dose of Epinephrine ( $\mu \mathrm{G} / \mathrm{kg}$ ) That Induced Dyskhythmias During Narcotic-Nitrous OXIDE ANAESTHESIA

\begin{tabular}{|c|c|c|c|c|}
\hline & & Supraventricular & Ventricular & VT or VF \\
\hline Morphine & $\begin{array}{l}1 \mathrm{mg} \cdot \mathrm{kg}^{-1} \\
2 \mathrm{mg} \cdot \mathrm{kg}^{-1}\end{array}$ & $\begin{array}{l}1.1 \pm 0.4(4 / 8) \\
0.9 \pm 0.4(4 / 8)\end{array}$ & $\begin{array}{l}1.9 \pm 0.3(3 / 8) \\
2.3 \pm 0.0(2 / 8)^{*}\end{array}$ & $\begin{array}{l}(0 / 8) \\
(0 / 8)\end{array}$ \\
\hline Fentanyl & $\begin{array}{l}0.01 \mathrm{mg} \cdot \mathrm{kg}^{-1} \\
0.02 \mathrm{mg} \cdot \mathrm{kg}^{-1}\end{array}$ & $\begin{array}{l}1.0 \pm 0.3(3 / 8) \\
1.0 \pm 0.2(3 / 8)\end{array}$ & $\begin{array}{l}1.5 \pm 0.8(4 / 8) \\
1.6 \pm 0.8(5 / 8)\end{array}$ & $1.9 \stackrel{(0 / 8)}{(V T, 1 / 8)}$ \\
\hline Meperidine & $\begin{array}{l}10 \mathrm{mg} \cdot \mathrm{kg}^{-1} \\
20 \mathrm{mg}^{-1} \mathrm{~kg}^{-1}\end{array}$ & $1.2 \pm \frac{0.6(4 / 8)}{0} \quad(0 / 8)$ & $\begin{array}{l}1.7 \pm 0.7(3 / 8) \\
1.6 \pm 0.6(3 / 8)\end{array}$ & $\begin{array}{l}(0 / 8) \\
(0 / 8)\end{array}$ \\
\hline
\end{tabular}

Mean $\pm \mathrm{SD}(\mathrm{N}=8)$; numbers in parentheses represent incidence of occurrence.

- Significantly larger $(P<0.05)$ than the corresponding doses required to produce supraventricular dysthythmias. Ventricular dysrhythmias are usually unifocal, not associated with bigeminy, and without pulse deficits.

TABLE 11

DOSE of EPINEPhrine ( $\mu G / K G$ ) That Induced DYskhythmias DuRing ANaEsthesia With Halogenated Inhalation Agents and Nitrous Oxide

\begin{tabular}{llcr}
\hline & Supraventricular & Ventricular & VT or VF \\
\hline Halothane & $2.9 \pm 1.8(6 / 8)$ & $3.6 \pm 1.7(8 / 8)$ & $5.6 \pm 1.5(5 / 8)$ \\
Enflurane & $2.3 \pm 1.5(6 / 8)$ & $3.2 \pm 1.4(8 / 8)$ & $5.5 \pm 1.6(3 / 8)$ \\
Methoxyflurane & $3.0 \pm 1.1(4 / 8)$ & $3.9 \pm 1.9(4 / 8)$ & 0 \\
\hline
\end{tabular}

Mean $\pm \mathrm{SD}(\mathrm{N}=8)$; numbers in parentheses represent incidence of occurrence. None of the arrhythmogenic doses are significantly different from each other $(P>0.05)$, but they are larger $(P<0.05)$ than the corresponding supraventricular and ventricular doses of Table 1; ventricular dysrhythmias are frequently multifocal and associated with bigeminy to quadrageminy with pulse deficits.

lease endogenous potassium from the liver, ${ }^{8}$ and cardiac dysrhythmias are potentiated by hyperkalaemia.s A mean peak serum potassium concentration of $6.5 \mathrm{mmol} / 1$ was obtained in this study following epinephrine infusion. None of the serum potassium measurements were higher than $7.0 \mathrm{mmol} / \mathrm{l}$ in any group. It has been reported that serum potassium between $6-9 \mathrm{mmol} / \mathrm{l}$ is a cardiac stimulant ${ }^{9.10}$ and would exert an insignificant dysihythmic effect on the heart below $6 \mathrm{mmol} / \mathrm{l}$. Therefore, changes in serum potassium among groups in this study do not appear to be an influential factor in the genesis of dysrhythmias induced by epinephrine.

In a preliminary report where halothane, enflurane, fluroxene and methoxyflurane were studied with nitrous oxide and oxygen or nitrogen and oxygen as inspired gas mixtures, the data suggested that the addition of nitrous oxide to the halogenated anaesthetics was more arrhythmogenic than the addition of nitrogen during epinephrine-induced ventricular dysrhythmias. ${ }^{7}$ The present study did not demonstrate significant differences of the arrhythmogenic doses among the halogenated-nitrous oxide anaesthetics (Table II). This lack of arrhythmic dose differences among halothane, enfiurane and methoxyflurane is different from published reports. ${ }^{2-4}$ However, it should be noted that all of these published studies were done without the addition of nitrous oxide. The addition of nitrous oxide to these halogenated general anuesthetics significantly decreased the arrhythmogenic dose of epinephrine in this study as compared with the previous studies, ${ }^{2-4}$ Nitrous oxide is known to have an $\alpha$-adrenergic stimulating action when administered with oxygen. ${ }^{11.12}$ This $\alpha$-adrenergic stimulating action of nitrous oxide is also evident when administered with other inhalation anaesthetics ${ }^{13-15}$ or morphine. ${ }^{16}$ However, whereas morphine-oxygen produced cardiac stimulation, the addition of nitrous oxide to morphine-oxygen produced cardiac depression. ${ }^{16}$ Pancuronium has also been shown to have a vagolytic effect on the heart in animals ${ }^{17}$ and cardiovascular stimulating effects in man. ${ }^{18}$ The interaction of nitrous oxide with the anaesthetics or narcotics is not well understood and is probably more complex with the addition of pancuronium. Failure to demonstrate different arrhythmic potentials of the haloge- 
nated agents to epinephrine infusion may be related to the addition of nitrous oxide and pancuronium. Methoxyflurane-nitrous oxide anaesthesia was not only associated with a lower incidence of ventricular dysrhythmias (4/8) in comparison with halothane-nitrous oxide (8/8) and enflurane-nitrous oxide (8/8), but also was not associated with any occurrence of ventricular tachycardia or ventricular fibrillation. When methoxyflurane was administered without the addition of nitrous oxide to dogs ${ }^{2}$ and goats, ${ }^{4}$ the alrhythmic doses of epinephrine were higher than those required during halothane anaesthesia, but the same as those required during enflurane anaesthesia. Methoxyflurane and enflurane are both ether derivatives and possess pharmacological actions similar to diethyl ether, which has potent cardiac stabilizing qualities against epinephrine-induced dysrhythmias.' The addition of nitrous oxide appears to antagonize the cardiac stabilizing effects of enflurane more than of methoxyflurane. Methoxyflurane with nitrous oxide has been advocated for anaesthetic management of phaeochromocytoma. ${ }^{19}$ where epinephrine-induced ventricular arrhythmias are a problem. In the present study, methoxyflurane-nitrous oxide anaesthesia was as effective as narcotic-nitrous oxide anaesthesia in preventing the occurrence of ventricular tachycardia and ventricular fibrillation.

The narcotic doses used in this study were aimed at meaningful doses for clinical anaesthesia and represent equipotent doses of morphine. fentanyl and meperidine. There are no published data on the "MAC" of narcotics. The preliminary report of Fraioli, et al. tend to suggest that $1 \mathrm{mg} \cdot \mathrm{kg}^{-1}$ of morphine sulfate and 60 per cent nitrous oxide are required to prevent movement of 50 per cent of patient in response to a skin incision; this is defined as the $0.5 \mathrm{MAC}$ equivalent of morphine. ${ }^{20}$ The lack of doseresponse relationship in the present study would suggest that the doses chosen were on the nearly flat portion of the dose-response curve. The complex interaction of nitrous oxide, pancuronium and narcotics noted above could also have influenced the results. The narcotic-nitrous oxide groups consistently required smaller doses of epinephrine to induce cardiac dysrhythmias. as compared with the halogenated-nitrous oxide groups, which was an unexpected finding. However, the ventricular dysrhythmias observed in the halogenated anaesthesia group were frequently multifocal with bigeminy to quadrageminy, with greater distortion of the QRS

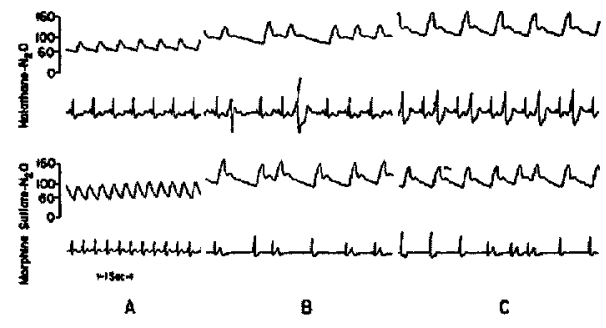

FIGURE I Arrhythmogenicity of epinephrine in dogs anaesthetized with morphine, $2 \mathrm{mg} \cdot \mathrm{kg}^{-1}$, and halothane, 1.2 MAC, with 50 per cent nitrous oxide with oxygen and pancuronium, $0.2 \mathrm{mg} \cdot \mathrm{kg}^{-1}$. A, Control. B. Onset of ventricular dysrhythmias following $3.9 \mu \mathrm{g} \cdot \mathrm{kg}^{-1}$ epinephrine infusion (halothane-nitrous oxide); following $2.3 \mu \mathrm{g} \cdot \mathrm{kg}^{-1}$ (morphine sulphatenitrous oxide). C. Following $5.7 \mu \mathrm{g} \cdot \mathrm{kg}^{-1}$ epinephrine infusion: halothane-nitrous oxide associated with bigeminy and pulse deficit; morphine sulphate-nitrous oxide associated with ventricular dysrhythmia without pulse deficit.

complexes and with pulse deficits (Figure 1). This type of rhythm led to more frequent ventricular tachycardia or fibrillation except during methoxyflurane-nitrous oxide anaesthesia. In contrast, the ventricular dysthythmias of the narcotic groups were of slower heart rate, with less distortion of the QRS complexes and without pulse deficits (Figure 1). The latter type of rhythm rarely led to ventricular tachycardia or ventricular fibrillation. The onset of ventricular dysrhythmias in the narcotic-nitrous oxide group was not usually preceded by bradycardia; whereas those observed in the halogenatednitrous oxide groups were usually preceded by bradycardia. Since there was no significant difference in peak blood pressure between the two groups, these findings tend to suggest that reflex bradycardia was blocked by narcotics with nitrous oxide, but not blocked by halogenated anaesthetic agents with nitrous oxide. Suppression of supraventricular pacemakers with bradycardia allows emergence of ventricular pacemakers. It is possible that anaesthesia with halothane or enfurane and nitrous oxide may also produce intrinsic ventricular conduction defects that potentiate ventricular dysrhythmias during epinephrine infusion. That larger doses of epinephrine are required before the onset of ventricular dysrhythmias in the halogenated nitrous oxide groups may possibly explain the increased incidence of ventricular tachycardia and ventricular fibrillation when they occurred. These results suggest that anaesthesia with narcotics or methoxyflurane, nitrous oxide and relaxants may 
stabilize the heart against serious epinephrineinduced ventricular dysrhythmias better than anaesthesia with halothane or enflurane with nitrous oxide and relaxant.

\section{SUMMARY}

The effects of epinephrine-induced dysrhythmias were evaluated in sixteen $15-20 \mathrm{~kg}$ mongrel dogs anaesthetized with halogenated inhalation agents, nitrous oxide and pancuronium and with narcotics, nitrous oxide and pancuronium. Group 1 consisted of eight animals which received 1.2 MAC halothane, enflurane or methoxyflurane in nitrous oxide and oxygen (2.5/2.5 litres) and Group 2 of eight animals which received morphine ( 1 and $2 \mathrm{mg} \cdot \mathrm{kg}^{-1}$ ), fentanyl (0.01 and $\left.0.02 \mathrm{mg} \cdot \mathrm{kg}^{-1}\right)$ and meperidine $(10$ and $20 \mathrm{mg} \cdot \mathrm{kg}^{-1}$ ) with nitrous oxide and oxygen (2.5/2.5 litres). Pancuronium $\left(0.2 \mathrm{mg} \cdot \mathrm{kg}^{-1}\right)$ was administered to both groups. Each animal in Group 1 or 2 was studied three times but only once a week and one anaesthetic regimen per study. The order of administration of the anaesthetic regimen was randomized for both groups.

Lead II of the electrocardiogram, oesophageal temperature and arterial pressure were monitored continuously. Arterial blood gases and serum sodium and potassium were determined during control, during the peak pressure response from epinephrine infusion and every $\mathbf{3 0}$ minutes for the rest of the study. Epinephrine $(5 \mu \mathrm{g} / \mathrm{ml})$ was infused at a rate of $1 \mu \mathrm{g} \cdot \mathrm{kg}^{-1} \cdot \mathrm{min}^{-1}$ up to ten minutes. The persistence of three or more consecutive dysrhythmic beats was used as the endpoint of the epinephrine arrhythmogenic dose. Arterial blood gases showed minimal changes in both groups during the course of the experiment with $\mathrm{Pa}_{\mathrm{O}_{2}} 24 \pm 2.13 \mathrm{kPa}$ (180 16 torr), $\mathrm{Pa}_{\mathrm{CO}_{2}} 4.8$ $\pm 0.4 \mathrm{kPa}$ (36 \pm 3 torr) and $\mathrm{cH}^{+} 43.65 \pm$ $0.14 \mathrm{nmol} / 1$ ( $\mathrm{pH} 7.36 \pm 0.07$ ). Serum sodium did not change significantly during the experiment, but serum potassium increased to a peak concentration of $6.5 \pm 0.4 \mathrm{mmol} / \mathrm{l}$ during the epinephrine infusion. The ventricular dysrhythmic dose of epinephrine was generally higher than the corresponding supraventricular dysrhythmic dose for each anaesthetic regimen for both groups. The arrhythmogenic doses for the halogenated-nitrous oxide anaesthesia groups were significantly higher than for the narcoticnitrous oxide groups; however, the incidence of ventricular arrhythmias was greater in the halogenated-nitrous oxide groups (20 of 24 vs 20 of
48). The incidence of ventricular arrhythmias was less in the methoxyflurane-nitrous oxide group (4/8) than in the halothane-nitrous oxide (8/8) or enflurane-nitrous oxide (8/8) groups. Ventricular tachycardia and ventricular fibrillation occurred in five of eight in the halothane group, three of eight in the enflurane group and in none of the eight in the methoxyflurane group. compared with an occurrence of one out of 48 epinephrine challenges in the narcotic-nitrous oxide groups. These results suggest that anaesthesia with narcotics or methoxyflurane with nitrous oxide and relaxants may stabilize the heart against serious epinephrine-induced ventricular dysthythmias better than anaesthesia with halogenated inhalation agents, nitrous oxide and relaxant.

\section{Résumé}

Cette étude porte sur les dysrythmies provoquées par l'épinéphrine sur 16 chiens de race commune anesthésiés aux halogénés et aux narcotiques. Un premier groupe de huit animaux a reçu de l'halothane, de l'enflurane ou du méthoxyflurane à une concentration équivalente a 1.2 fois la concentration alvéolaire minimale alors que le deuxième groupe recevail de la morphine à la dose de 1 et $2 \mathrm{mg} \cdot \mathrm{kg}^{-1}$, du fentanyl à 0.01 et $0.02 \mathrm{mg} \cdot \mathrm{kg}^{-1}$ ou de la mépéridine 10 et $20 \mathrm{mg} \cdot \mathrm{kg}^{-1}$. Du protoxyde d'azote et de l'oxygène à 50 pour cent ainsi que du pancuronium ont été administrés aux deux groupes avec les produits mentionnés. Chacun des animaux a été étudié trois fois mais jamais plus d'une fois par semaine et un seul produit a été employé par séance. L'ordre d'administration des agents a été randomisé pour les deux groupes.

La dérivation II de l'électrocardiogramme, la température cesophagienne et la pression artérielle ont été suivis de façon continuelle. On a analysé les gaz du sang ainsi que la concentration du sodium et du potassium pendant la période de contrôle, pendant l'infusion d'épinéphrine et à toutes les trente minutes jusqu'à la fin de l'étude. Une solution d'épinéphrine $(5 \mu \mathrm{g} / \mathrm{ml})$ a été perfusée à ta vitesse de $1 \mu \mathrm{g} \cdot \mathrm{kg}^{-1} \cdot \min ^{-1}$ pendant dix minutes ou moins. Le temps d'arrêt de la perfu. sion a été dèterminé par la persistance de trois battements dysrythmiques ou plus. Les gaz du sang et le sodium ont été peu modifiés pendunt l'expérience alors que le potassium s'élevait à une concentration de $6.5 \pm 0.4 \mathrm{mmol} / \mathrm{l}$ au cours de la perfussion. Dans les deux groupes d'animaux, la dose d’épinéphrine requise pour pro- 
voquer une dysrythmie ventriculaire était en génêrale plus forte que celle requise pour une dysrythmic supraventriculaire. La dose arythmogène pour le groupe halogéné-protoxyde d'azote à été de façon significative plus élevée que pour le groupe narcotique-protoxyde; cependant l'incidence d'arythmies ventriculaires a été plus marquée dans le groupe qui avait reçu un agent halogéné (20 chiens sur 24 comparativement à 20 sur 48 ). L'incidence d'arythmies ventriculaires a été moindre pour les chiens anesthésiés au méthoxyflurane-protoxyde d'azote (4 sur 8) qu'à l'halothane-protoxyde (8 sur 8 ) ou l'enflurane-protoxyde ( 8 sur 8 ). De la tachycardie et de la fibrillation ventriculaires sont survenues sur cing des huit chiens du groupe halothane, sur trois sur huit du groupe enflurane et sur aucun sur huit du groupe méthoxyflurane, comparativement à un seul chien du groupe des narcotiques sur 48 . Ces résultats permettent de conclure que l'anesthésie produite par un narcotique ou du méthoxyflurane auxquels on associe du protoxyde d'azote et un myorésolutif protège le cour contre les dysrythmies ventriculaires graves provoquées par l'épinéphrine mieux que les autres halogénés associẻs aux mèmes produits.

\section{ACKNOWLEDGEMENT}

The authors thank Mrs. Vicky Larsen for preparation of this manuscript.

\section{REFERENCES}

I. Meek, W.J., Hathaway, J.R. \& ORTh, O.S. Effects of ether, chloroform and cyclopropane on cardiac automaticity. J. Pharmacol. Exp. Ther. 61: 240 (1937)

2. Munson. E.S. \& Tucker, W.K. Doses of epinephrine causing arrhythmia during enflurane, methoxyfurane and halothane anesthesia in dogs. Canad. Anaesth. Soc. J. 22: 495 (1975).

3. JoAs, T.A. \& Stevens, W.C. Comparison of the arrhythmic doses of epinephrine during forane, halothane and fluroxene anesthesia in dogs. Anesthesiology $35: 48(1971)$.

4. Zahed, B., Miletich, D.J., IVANKOVICH. A.D., et $\alpha$. Arrhythmic doses of epinephrine and dopamine during halothane, enfurane, methoxyflurane and fluroxene anesthesia in goats. Anesth. Analg. 56: 207 (1977).

5. KATZ, R.L. \& EPSTEIN, R.A. The interaction of anesthetic agents and adrenergic drugs to produce cardiac arrhythmias. Anesthesiology 29: 763 (1968).

6. EgER, E. 1. II. Anesthetic Uprake and Acrion. Chapter I-MAC. Baltimore: William \& Wilkins Co.,p. 5 (1974).

7. Wong, K.C., Shaw, C.L. \& Blatnick, R.A. Epinephrine-induced dysrhythmias: the effect of nitrous oxide with halothane. enflurane, fluroxene or methoxyflurane. A.S.A. Abstracts Scientific Papers, p. 91 (1977).

8. D'SILVA, J.L. The action of adrenaline on serum potassium. J. Physiol., Lond. 86: 219 (1936)

9. Wong, K.C.. Kawamura, R.. Hodges, M.R. . et al. Acute intravenous administration of potassium chloride to furosemide pretreated dogs. Canad. Anaesth. Soc. J. $24: 203$ (1977).

10. Surawicz, B. \& GeTres, L.S. Two mechanisms of cardiac arrest produced by potassium. Circulation Res. 12:415 (1963).

11. EISELE, J.H. \& SMITh. N.T. Cardiovascular effects of $40 \%$ nitrous oxide in man. Anesth. Analg. $51: 956(1972)$.

12. LunN, J. K., Liu, W. S.. Gentry, S.. EnGlish, J.B. \& Stanley, T.H. Peripheral vascular versus cardiac effects of nitrous oxide in the bovine. Canad. Anaesth. Soc. J. $24: 571$ (1977).

13. SMith. N.T. \& Corbascio, A.N. The cardiovascular effect of nitrous oxide during hilothane anesthesia in the dog. Anesthesiology 27:560 (1966).

14. Smith, N.T., Eger, E.l. II, Gregory, G.A. Cullen. B.F. \& CUlLeN, D.J. The cardiovascular response to the addition of nitrous oxide to diethyl ether in man. Canad. Anaesth. Soc. J. 19:42 (1972).

15. Bennet, G.M., Loeser, E.A., Kawamura, R. \& STANley, T.H. Cardiovascular responses to nitrous oxide during enflurane and oxygen anesthesia. Anesthesiology 46: 227 (1977).

16. Wong, K.C., Martin, W.E., Hornbein, T.F. FREUND, F.G. \& EVERETT, J. The cardiovascular effects of morphine sulfate with oxygen and with nitrous oxide in man. Anesthesiology $38: 542$ (1973).

17. SAXENA, P.R. \& BonTA, I. L. Mechanism of selective cardiac vagolytic action of pancuronium bromide: Specific blockade of cardiac muscarinic receptors. Eur. J. Pharmacol. H: 332 (1970).

18. Stoelting, R.K. The hemodynamic effects of pancuronium and d-tubocurarine in anesthetized patients. Anesthesiology 36: 612 (1972),

19. Crout, J.R. \& Brown, B.R. Anesthetic management of pheochromocytoma: the value of phenoxybenzamine and methoxyflurane. Anesthesiology 30: 29 (1969)

20. WONG, K.C. (discussion). Stoelting, R.K., Creasser, C.W., Gibe, P.S., et al. Circulatory effects of halothane added to morphine anesthesia in patients with coronary-artery disease. Anesth. Analg. $53 ; 454$ (1974). 